Nr 1(70), 2021, s. 99-110

https://doi.org/10.12797/Politeja.18.2021.70.08

\author{
Magdalena ROGUSKA-NÉMETH (D) \\ Uniwersytet Warszawski \\ m.roguska@uw.edu.pl
}

\title{
W SPADKU PO RODZICACH
}

\section{O PROCESACH REKONSTRUOWANIA TOŻSAMOŚCI W NARRACJACH AUTORÓW TRANSJĘZYCZNYCH POCHODZENIA WĘGIERSKIEGO}

\section{ABSTRACT Inherited from Parents: Identity Reconstruction Processes in the Narratives of Translingual Writers of Hungarian Origin}

Translingualism in the context of literature is a phenomenon that describes the works of authors who do not write in their mother tongue. Their works are narratives that transcend the boundaries of cultures and literary conventions and, as such, are not easily definable and analyzable. This fact is often the reason why their works are marginalized. The article is an analysis of works written by two authors of Hungarian origin. The first one, Viviane Chocas, writes in French, while the second, Melinda Nadj Abonji, in German. Both are therefore translingual, although this is not their only point of similarity. Their works are clearly autobiographical and both describe a similar process: that of the reconstruction of Hungarian identity, which was suppressed by their parents or blurred in earlier generations. That fact entitles us to look at their works from the point of view of the so-called post-memory, a phenomenon first described by Marianne Hirsch. In the course of the analyses, it turns out that the protagonists of the discussed works have a different attitude to their parents' heritage and adopt different strategies of dealing with the past. While Ildikó, the protagonist of Melinda Nadj Abonji's novel, decides to cut off both symbolically and physically from the past, Klara, from the novel by Viviane Chocas, feels an irresistible urge to learn about the difficult fate of her ancestors.

Keywords: Hungarian literature, translingualism, identity, postmemory

Słowa kluczowe: literatura węgierska, transjęzyczność, tożsamość, postpamięć 


\section{WPROWADZENIE}

W lutym 2020 r. dyrektor Petőfi Irodalmi Múzeum', publicznej instytucji odpowiedzialnej za gromadzenie, przechowywanie i prezentowanie zabytków literatury węgierskiej, opublikowal na łamach internetowego portalu Mandiner artykuł pod wymownym tytułem Kim jest wegierski pisarz?2. Odpowiedź na zadane w tytule pytanie brzmiała następująco: wegierski pisarz to ktoś, kto pisze po wegiersku [podkr. M.R.-N.], dla wegierskiego czytelnika i kto chce, by za sto lat również czytali go Wegrzy3. Formułując powyższą definicję, Szilárd Demeter miał na celu napiętnowanie wszystkich tych autorów, którzy piszą i publikują swoje książki z myślą o zewnętrznym rynku wydawniczym (cokolwiek miałoby to w praktyce oznaczać), jako tych, którzy są skoncentrowani na karierze międzynarodowej i zapominają o węgierskich czytelnikach: Chca być kimkolwiek innym, byle nie Wegrami. Bycie wegierskim pisarzem jest dla nich obciachem. [...] sa przekonani, że gdyby urodzili się kilkaset kilometrów dalej, cieszyliby się światowa stawą.

Pisząc powyższe słowa, mniej lub bardziej świadomie pozbawił on jednak prawa do nazywania (siebie) pisarzami węgierskimi również tych, którzy pomimo węgierskiej narodowości nie piszą po węgiersku, a co za tym idzie ich utwory nie są skierowane do węgierskojęzycznego czytelnika.

Wypowiedź Demetera nie zasługiwałaby pewnie nawet na uwagę (tym bardziej że z merytorycznego punktu widzenia jest ona co najmniej wątpliwa), gdyby nie padła z ust człowieka, który odpowiedzialny jest na Węgrzech za rozdysponowywanie publicznych funduszy wśród osób zajmujących się literaturą. Jak można z niej wnioskować, dla dyrektora PIM-u wszyscy ci autorzy, którzy nie wpisują się w powyższą definicję, są grupą wyłączoną, „niezasługującą na wsparcie” czy wręcz niepożądaną. Jak konstatuje bowiem Demeter: Nie ma sensu wydawać na nich publicznych pieniędzy. Bytaby to inwestycja bezzwrotna. Lepiej wspierać tych pisarzy, którzy chca być stawni na Wégrzech - a jeśli zyskają stawe za granica, pozostana dumnymi Wegramis.

Idąc tokiem rozumowania Demetera, do grupy „nie-Węgrów” należałoby włączyć również bohaterki niniejszego artykułu. Będą nimi dwie autorki pochodzenia węgierskiego: pisząca po niemiecku Melinda Nadj Abonji ${ }^{6}$ oraz frankofońska autorka Viviane

Muzeum Literatury im. Sándora Petőfiego, w skrócie PIM.

2 Szilárd Demeter, Ki a magyar író?, [online] https://mandiner.hu/cikk/20200224_ki_a_magyar_iro, 28 IV 2020.

3 [...] magyar író az, aki magyarul ír magyar olvasónak, és azt akarja, hogy száz év múlva is magyarok olvassák [te i kolejne tłum. M.R.-N.]. Tamże.

4 Bármi mások akarnak lenni, csak nem magyarok. Magyar irónak lenni nekik snassz. [...] meg vannak gyözödve arról, hogy ha pár száz kilométerrel arrébb születnek, akkor világhirüek lennének. Tamże.

5 Örájuk kár közpénzt költeni. Nem megtérülö befektetések. Akkor már inkább azokat az irókat érdemes támogatni, akik magyarhirüek akarnak lenni - és amennyiben világhirüekké válnak, akkor is büszke magyarok maradnak. Tamże.

6 Melinda Nadj Abonji pochodzi z Wojwodiny, autonomicznej prowincji położonej na terenie Serbii. Urodziła się w 1968 r. w Bečej (dawne węg. Óbecse). Gdy miała pięć lat, wyemigrowała z rodziną do Szwajcarii, w której mieszka do dzisiaj. Wydała dwa utwory prozatorskie. W 2004 r. ukazała się jej pierwsza (i nieprzetłumaczona jak dotąd na język polski) powieść pod tytułem Im Schaufenster 
Chocas ${ }^{7}$. Węgierskie korzenie nie są jednak ich jedynym punktem wspólnym. Obie podejmują w swoich wyraźnie autobiograficznych tekstach próbę zrekonstruowania wypartej przez ich rodziców bądź rozmytej we wcześniejszych pokoleniach węgierskiej tożsamości. Pomimo swojej transjęzyczności ${ }^{8}$ są zatem bardziej „węgierskie”, niż mogłoby się to początkowo wydawać. Jednakże twórczości żadnej z nich nie da się jednoznacznie zaklasyfikować ani do literatury węgierskiej, ani do żadnej innej tradycyjnie pojmowanej literatury narodowej, co może być powodem marginalizowania ich twórczości. I tak, z jednej strony ich „egzotyczność” może być literacko pociągająca, a zarazem z punktu widzenia rynków wydawniczych atrakcyjna. $Z$ drugiej jednak jako nieprzynależące w pełni do żadnej z literatur są one często lokowane w pozycji „innego" oraz spychane na margines krytycznoliterackiej i literaturoznawczej debaty, odbywającej się w ramach narodowych kanonów.

Znamienna w tym kontekście jest wypowiedź mieszkającej w Szwajcarii Nadj Abonji, która zapytana o to, czy uważa się za pisarkę węgierską, odpowiedziała: Nie, jestem po prostu pisarką. [...] Nie chcę być częścią żadnego narodu. W życiu zetknętam sie z różnymi krajami, ale nie jest moim zadaniem jako pisarki deklarowanie przynależności do któregokolwiek z narodów. Nie ma to dla mnie znaczenia, koniec końców poruszam się w kosmopolitycznym środowisku?.

Jak wynika z przytoczonego fragmentu, Nadj Abonji nie czuje specjalnej więzi z żadnym narodem i uważa się za obywatelkę świata. Ta dość asekuracyjna postawa (w pewnym stopniu zapewne podyktowana również poprawnością polityczną) stoi jednak w sprzeczności z przekazem, który wyłania się z twórczości autorki. W jej debiutanckiej powieści pt. Gotębie wzlatują ${ }^{10}$ problem przynależności (lub nie) do określonej wspólnoty jest bowiem jedną z kluczowych kwestii.

Tematyka podejmowana przez autorki analizowanych utworów upoważnia nas do spojrzenia na ich teksty z perspektywy tzw. postpamięci, zjawiska opisanego po raz pierwszy przez Marianne Hirsch ${ }^{11}$. Tzw. pamięć oddziedziczona lub postpamięć to pamięć drugiego pokolenia, czyli potomków tych, którzy przeżyli zbiorową traumę.

im Frühling, a w 2010 nagrodzona dwiema prestiżowymi nagrodami - Deutscher Buchpreis oraz Schweizer Buchpreis - powieść, będąca przedmiotem analizy w niniejszym artykule: Gotębie wzlatują.

7 Viviane Chocas urodziła się w 1962 r. już poza granicami Węgier, skąd pochodzą jej rodzice. Dorastała i pobierała nauki w Paryżu. Obecnie pracuje jako dziennikarka i reporterka. Jest autorką dwóch utworów prozatorskich: Bazar Magyar (2006) i Je vais beaucoup mieux que mes copains morts (2012).

8 Więcej na temat transjęzyczności zob. np.: Switching Languages. Translingual Writers Reflect on Their Craft, red. S.G. Kellman, Lincoln-London 2003; T. Steinitz, Translingual Identities. Language and the Self in Stefan Heym and Jakov Lind, Rochester, NY 2013.

9 Nem, én egyszerüen író vagyok. Nem szeretnék egyetlen nemzet mellett sem elkötelezödni. Életem során különféle országokkal kerültem kapcsolatba, de iróként nem feladatom, hogy valamely nemzet részeként határozzam meg magam. Számomra ez nem fontos, elvégre kozmopolita környezetben mozgok. Diktatúrát Svájcban, Techet Péter beszélgetése Melinda Nadj Abonjival, „Heti Válasz” 2011, 13 I, r. IX, nr 2, s. 40.

10 M. Nadj Abonji, Gotębie wzlatują, przeł. E. Kalinowska, Wołowiec 2012.

11 M. Hirsch, Żatoba i postpamięć, przeł. K. Bojarska, [w:] Teoria wiedzy o przesztości na tle wspótczesnej humanistyki. Antologia, red. E. Domańska, Poznań 2010, s. 247-280. 
Termin ten stosowany jest głównie w kontekście ofiar dzieci Holokaustu, ale może odnosić się również do społeczeństw, których w jakimś momencie historii dotknęła zbiorowa trauma ${ }^{12}$. Bohaterki analizowanych utworów to potomstwo węgierskich emigrantów, którzy w drugiej połowie XX w. najczęściej z powodów politycznych zmuszeni byli opuścić rodzinny kraj. Większość z nich osiedliła się w Europie Zachodniej (m.in. w Austrii, Francji, Szwajcarii, Wielkiej Brytanii), część po pewnym czasie wyemigrowała za ocean, głównie do Stanów Zjednoczonych, Kanady i Argentyny. Wyjazd z ojczyzny bardzo często okupiony był traumą ${ }^{13}$, która towarzyszyła zarówno doświadczeniom w ojczyźnie, jak i w kraju przyjmującym, a której pokłosiem było wyparcie węgierskiej tożsamości. Taki los spotkał też m.in. rodziców bohaterek utworów, które będą przedmiotem analiz w niniejszym artykule. Głównym celem będzie przyjrzenie się temu, w jaki sposób z niewyleczoną traumą rodziców poradziły sobie ich dzieci.

\section{TRUDY ASYMILACJI I HOMO BALCANICUS}

Pierwszym analizowanym utworem jest powieść Melindy Nadj Abonji pod tytułem Gotębie wzlatują. Jego główną bohaterką, a zarazem pierwszoosobową narratorką jest Ildikó Kocsis. Wraz z młodszą siostrą Nomi opuszcza ona rodzinną miejscowość w Wojwodinie ${ }^{14}$, aby dołączyć do rodziców, którzy niemal cztery lata wcześniej wyemigrowali do Szwajcarii. Tam dorasta, kończy szkołę i rozpoczyna studia, nawiązuje pierwsze przyjaźnie, zakochuje się. Rodzice Ildikó podejmują wszelkie możliwe wysiłki, aby przystosować się do życia w zachodnim społeczeństwie. Mimo to początkowo codzienność Kocsisów daleka jest od idylli. Wszyscy członkowie rodziny są zaangażowani w ciężką pracę w pralni. Ich sytuacja ulega poprawie dopiero kilka lat później, gdy po zdaniu egzaminu z wiedzy o państwie i pozytywnym głosowaniu społeczności miasta uzyskują szwajcarskie obywatelstwo. Ukoronowaniem ich starań jest przejęcie od szwajcarskiej rodziny popularnej kawiarni Mondial w centrum miasta.

12 Więcej na temat postpamięci zob. np.: D. LaCapra, Historia w okresie przejściowym. Doświadczenie, tożsamość, teoria krytyczna, przeł. K. Bojarska, Kraków 2009; A. Mach, Świadkowie świadectw. Postpamięć zagtady w polskiej literaturze najnowszej, Warszawa-Toruń 2016; Migracyjna pamięć, wspólnota, tożsamość, red. R. Sendyka, T. Sapota, R. Nycz, Warszawa 2016; Modi memorandi. Leksykon kultury pamięci, red. M. Saryusz-Wolska, R. Traba; współpr. J. Kalicka; rada nauk. P. Czapliński [i in.], Warszawa 2014; „Politeja” 2015, vol. 12, nr 3(35) Oblicza postpamięci; „Politeja” 2017, vol. 14, nr 2(47) Oblicza postpamięci 2; „Politeja” 2020, vol. 17, nr 2(65) Oblicza postpamięci 3; Od pamięci biodziedzicznej do postpamięci, red. T. Szostek, R. Sendyka, R. Nycz, Warszawa 2013; D. Utracka, Trauma i uwznioślenie. Postpamięćjako kategoria narracyjna (na przyktadzie „Matej Zagtady” Anny Janko), [w:] Tożsamość, kultura, nowoczesność, T. 1, red. B. Morzyńska-Wrzosek, M. Kurkiewicz, I. Szczukowski, Bydgoszcz 2017, s. 221-243; Wojna i postpamięć, red. Z. Majchrowski, W. Owczarski, Gdańsk 2011.

13 Na temat traumy zob. np.: Antologia studiów nad trauma, red. T. Łysak, przeł. T. Bilczewski i in., Kraków 2015.

14 Wojwodina - autonomiczna prowincja w północnej Serbii, zamieszkana przez przedstawicieli wielu grup etnicznych, głównie Serbów (ok. 67\%) i Węgrów (ok. 13\%), ale również m.in. przez Słowaków, Chorwatów, Romów, Rumunów i Czarnogórców. W Wojwodinie obowiązuje sześć języków urzędowych, co odzwierciedla zróżnicowany skład etniczny i językowy regionu oraz jego bogate tradycje kulturowe. 
Kocsisowie dokładają wszelkich starań, by zdobyć uznanie dotychczasowych klientów kafeterii. Szybko okazuje się jednak, że wytężona praca nie wystarcza, aby mogli być traktowani na równi z rodowitymi Szwajcarami. Przez odwiedzających kawiarnię uważani są za obcych i budzą w związku z tym skrajne emocje: $\mathrm{z}$ jednej strony intrygują i fascynują, z drugiej zaś są źródłem lęku i nienawiści. W oczach większości jawią się jako homo balcanicus: emigranci z krajów ogarniętej wojną Jugosławii, zacofany lud, który nie przeszedt jeszcze oświecenia ${ }^{15}$.

Najboleśniej przekonują się o tym, gdy ktoś z eleganckich, zadbanych i na pozór życzliwych im gości wysmarowuje ściany kawiarnianej toalety fekaliami. Znamienne jest w tym kontekście to, jak reagują na zajście poszczególni członkowie rodziny Kocsisów. Podczas gdy matka i ojciec przyjmują zdarzenie z milczącą pokorą, w myśl zasady, że ludzkie traktowanie ze strony Szwajcarów trzeba sobie najpierw wypracować ${ }^{16}$, Ildikó czuje się głęboko rozczarowana i rozgoryczona. Nieprzyjemny incydent jest bowiem w jej oczach potwierdzeniem tego, że Kocsisowie nigdy nie byli, ale też nie będą traktowani w Szwajcarii jak „swoi”.

Zapewne dlatego też pod względem emocjonalnym zarówno dla niej, jak i dla jej siostry dużo ważniejsza od Szwajcarii jest Wojwodina, którą Kocsisowie odwiedzają raz na kilka lat przy okazji rodzinnych uroczystości. Mimo sporadycznych wizyt związek sióstr z miejscem urodzenia wydaje się być nieporównanie silniejszy niż z niemało im przecież oferującą Szwajcarią. Dzieje się to poniekąd wbrew woli ich ojca, który otwarcie manifestuje krytyczny stosunek do szeroko pojętego Wschodu, będącego w jego mniemaniu metonimią ,wszystkiego, co najgorsze”. Komuniści zniszczyli mu życie, powie kiedyś mama, pytana przez swoje córki o to, od jakich koszmarów z przesztości [...] uwalniaja ojca alkoholowe ekscesy ${ }^{17}$. Odpowiedź ta z jednej strony niewiele rozjaśnia małym jeszcze wówczas dziewczynkom, z drugiej nie ma też jednak większego wpływu na to, jaką rolę odgrywa Wojwodina w procesie kształtowania przez nie tożsamości. Rodzinne strony darzą one miłością bezwarunkową, a ich niezmienność jest dla Ildikó i jej siostry Nomi głównym punktem odniesienia w ich tożsamościowych poszukiwaniach.

Ildikó do końca pozostaje rozdarta między Szwajcarią, w której mieszka, a miejscem urodzenia, w którym spędziła pierwsze lata życia. Warto jednak podkreślić, że nie mamy tu do czynienia z prostą binarną opozycją, w której Szwajcaria utożsamiana byłaby z „obcością”, a Wojwodina ze „swojskością”. Dobitnie świadczą o tym kolejne wizyty rodziny Kocsisów u węgierskich krewnych, którzy postrzegają ich jak przybyszy z dalekiego i dla zdecydowanej większości z nich nieosiągalnego Zachodu. Kocsisowie budzą przesadną sensację, ponieważ zdecydowanie wyróżniają się na tle wojwodińskiej wsi, chociażby ze względu na nietuzinkowe stroje. Symbolem ich awansu, a zarazem wykluczenia z lokalnej społeczności jest również klimatyzowany, ciemnobrązowy chevrolet, który gładko sunie po wyboistych drogach serbskiej wsi i wzbudza podziw męskiej części węgierskiej diaspory. Wreszcie bolesnym powodem wyobcowania Kocsisów

15 M. Nadj Abonji, Gotębie wzlatują..., s. 81.

16 Tamże, s. 212.

17 Tamże, s. 23. 
jest to, że nie mogą oni brać udziału w większości ważnych dla ich rodziny wydarzeń i nie potrafią ,"na odległość” przeżywać emocji z nimi związanych. Izolację pogłębia dodatkowo wybuch wojny na Bałkanach. Kocsisowie boją się o swoich bliskich, ale nie są w stanie im pomóc i są zmuszeni do przeżywania dramatu, który dotkną ich ojczyznę, jedynie pośrednio.

\section{TOŻSAMOŚCIOWA UKŁADANKA}

W perspektywie całego opisanego w powieści okresu z życia Kocsisów niezbyt częste, ale jednak regularne powroty do Wojwodiny wyznaczają rytm życia rodziny. W powieści opisanych jest pięć podróży, które przeplatane są obrazami ze Szwajcarii. Wizyty w rodzinnych stronach nie mają charakteru przypadkowego i związane są zawsze z ważnym wydarzeniem lub uroczystością o charakterze rodzinnym. Rodzice Ildikó podróżują do Wojwodiny wyłącznie z poczucia obowiązku. Dla ojca każde odwiedziny oznaczają bowiem rozdrapanie starych ran i przypomnienie bolesnych wydarzeń, które skłoniły go do wyjazdu z ojczyzny. Inaczej sprawa ma się w przypadku Ildikó, w której życiu podróże w rodzinne strony pełnią funkcję tożsamościotwórczą oraz wiążą się z ciągłym ponawianiem pytania: „kim jestem”. W dłuższej perspektywie mają natomiast na celu zrekonstruowanie konsekwentnie wypieranej przez jej rodziców (a w szczególności przez ojca) węgierskiej tożsamości.

Ostatecznie Ildikó nie opowiada się po żadnej ze stron i decyduje się na zastąpienie pytania „kim jestem” pytaniem „kim mogę się stać”. Dochodzi do tego jednak stopniowo. Ildikó najpierw symbolicznie żegna się zarówno z Wojwodiną, jak i ze Szwajcarią, co pozwala jej stworzyć pole do skonstruowania nowej, nieskażonej przeszłością i niezakorzenionej w żadnym z narodów tożsamości.

Pierwszym przełomowym w tym kontekście wydarzeniem jest odejście kochającej babci Ildikó, nazywanej przez nią i jej siostrę Mamiką. Jej śmierć w granicznym 1989 r. jest równoznaczna z zamknięciem pewnego etapu w życiu bohaterki, a z praktycznego punktu widzenia wiąże się z kilkunastoletnią przerwą w podróżach do Wojwodiny.

Drugim przełomowym momentem jest z kolei wybuch wojny na Bałkanach, który ostatecznie odcina Kocsisów od rodziny i boleśnie uświadamia im, że nie mają najmniejszego wpływu na to, co się z nią dzieje, a jedyne, co mogą uczynić, to obserwować z oddali cierpienie swoich bliskich. Konsekwencją dramatycznych wydarzeń mających miejsce w rodzinnych stronach bohaterki jest ponadto to, że zmuszona jest ona porzucić swoje plany powrotu do ojczyzny.

Zwieńczeniem tożsamościowych poszukiwań Ildikó jest swoista przemiana bohaterki ze skazanej na wieczne poczucie obcości migrantki w niczym nieskrępowanego nomadę. Podczas gdy życie pierwszej naznaczone było tęsknotą i nostalgią, a przeszłość związana z ojczyzną stanowiła rodzaj piętna, wpływającego na to, jak odbierała rzeczywistość, jako nomada (w rozumieniu tego pojęcia przez Rosi Braidotti ${ }^{18}$ ) nie jest już

18 Na ten temat zob. R. Braidotti, Podmioty nomadyczne. Ucieleśnienie i różnica seksualna w feminizmie wspótczesnym, przeł. A. Derra, Warszawa 2009. 
przywiązana do jednego miejsca, jest „pomiędzy” miejscami, w ciągłej mentalnej podróży, nie tęskni za ojczyzną, bo nie ma też jej jednej, a każde miejsce może się nią stać choćby na chwilę.

Do przemiany bohaterki dochodzi, gdy po incydencie w toalecie Mondialu Ildikó decyduje się diametralnie zmienić swoje życie, odejść z pracy w kawiarni i wyprowadzić się z rodzinnego domu. Jej decyzji nie rozumieją rodzice, dla których wyprowadzka córki oznacza porażkę i jest równoznaczna z zanegowaniem wszystkiego tego, co udało im się w Szwajcarii osiągnąć. Nieprzypadkowo nowe mieszkanie Ildikó położone jest przy tzw. zachodniej obwodnicy miasta, po której przez cały dzień suną sznury samochodów. Apartament przy autostradzie jest czytelną metaforą tymczasowości, podobnie zresztą jak brak zasłon w oknach i nierozpakowane kartony, które wprawiają ojca bohaterki w zdumienie. Ildikó nie traktuje nowego miejsca zamieszkania jak domu, lecz jak pierwszy przystanek w rozpoczynającej się właśnie dla niej podróży, co nie znaczy, że całkowicie odcina się ona od korzeni. Ostatnia scena powieści jest opisem wizyty Ildikó i Nomi na cmentarzu w dzień Wszystkich Świętych. Nomi wpada na pomysł, jak przestać ciagle omijać ten dzień i przywrócić mu należne znaczenie ${ }^{19}$. Siostry składają kwiaty na zbiorowej mogile, wspominając wszystkich tych, którzy „zostali w Wojwodinie na zawsze”.

\section{JEDZENIE A WĘGIERSKOŚĆ}

Rekonstrukcji wypartej we wcześniejszych pokoleniach tożsamości podejmuje się również Klára, bohaterka napisanego w języku francuskim autobiograficznego utworu autorstwa Viviane Chocas, urodzonej w Paryżu dziennikarki i reporterki o węgierskich korzeniach. Wydany w 2006 r. Bazar magyar ${ }^{20}$ [„Madziarski bazar”] opowiada historię dziewczyny, której rodzice - Zsuzsa i Péter - po powstaniu węgierskim 1956 r. wyemigrowali do Paryża. Dramatyczne okoliczności wyjazdu z ojczyzny (kłótnia Pétera ze swoją matką, która obwiniała go o śmierć ojca) sprawiły, że dwudziestodwuletni wówczas Péter podjął decyzję o odcięciu się od przeszłości i zerwaniu wszelkich kontaktów z rodziną. Wraz z żoną dołożyli też wszelkich starań, by zapomnieć o tym, co zostawili na Węgrzech, i zacząć życie zupełnie od nowa. Aby nie obciążać córki przeszłością, postanowili wychować ją na Francuzkę - rozmawiali z nią wyłącznie po francusku, a ich życie sprzed emigracji owiane było tajemnicą. Co więcej, po uzyskaniu francuskiego obywatelstwa zmienili też nazwisko z węgierskiego Szelényi, na którym „łamały sobie język nauczycielki Kláry”21, na francusko brzmiące Séli. Węgrami pozostali jedynie przy stole, a co za tym idzie węgierskość Kláry sprowadzała się wyłącznie do węgierskich smaków z kuchni jej matki. To jedzenie było zatem dla Kláry bodźcem, który skłonił ją do podjęcia próby zrekonstruowania węgierskiej tożsamości.

\footnotetext{
19 M. Nadj Abonji, Gotębie wzlatują..., s. 229.

20 V. Chocas, Bazar magyar, Paris 2006.

21 Tamże, s. 22.
} 
Pierwszym krokiem, który podjęła, notabene w tajemnicy przed wszystkimi, było rozpoczęcie nauki języka węgierskiego. Jej rodzice nigdy nie rozmawiali przy córce w swoim języku ojczystym, a węgierszczyznę miała okazję słyszeć wyłącznie przy okazji zakupów w paryskim sklepie z węgierską żywnością państwa Subów, który jeszcze jako mała dziewczynka odwiedzała od czasu do czasu wraz z ojcem. Po zaledwie ośmiu miesiącach nauki zdecydowała się na podejście do egzaminu maturalnego z języka węgierskiego, który zakończył się dla niej sukcesem, bardziej jednak dzięki życzliwości egzaminatora aniżeli jej faktycznym umiejętnościom językowym. Rodzice bohaterki nigdy nie dowiedzieli się o tym, że ich córka zdała maturę z węgierskiego, dla niej samej było to jednak niezwykle ważne wydarzenie. Po raz pierwszy bowiem nie tylko przed samą sobą, ale również przed innymi otwarcie przyznała, że jest dzieckiem emigrantów.

Od tej pory starała się wykorzystywać każdą nadarzającą się okazję ku temu, by obcować z językiem węgierskim i węgierską kulturą. Uczestniczyła w paryskich wieczorach poezji węgierskiej, słuchała koncertów węgierskich muzyków, brała udział w festiwalach filmów znad Dunaju, aż w wieku 24 lat po raz pierwszy sama wyjechała na Węgry. Na jednej z budapeszteńskich ulic poznała wówczas młodego fotografa, Pála, którego uwagę przykuł strój Kláry, wyróżniający ją spośród reszty przechodniów. Kiedy zapytał on bohaterkę o narodowość, ta najpierw bez wahania odpowiedziała, że jest Francuzką. Po chwili skorygowała jednak swoją odpowiedź, dodając, że jej rodzice są Węgrami, a ona sama mówi trochę po węgiersku. To pozornie błahe stwierdzenie było tak naprawdę wypowiedzianą na głos deklaracją przynależności do więcej niż jednego narodu i kolejnym krokiem zbliżającym Klárę do odzyskania odebranego jej poniekąd przez rodziców węgierskiego „ja”.

\section{EKSTAZA I TRUDNE DZIEDZICTWO}

Z punktu widzenia tożsamościowych poszukiwań bohaterki na szczególną uwagę zasługuje scena opisująca doznania, które przyniosło Klárze skosztowanie czerwonej papryki. Ta chętnie stosowana przez Węgrów przyprawa jest głównym składnikiem potraw, które serwowane były podczas obiadu zjedzonego przez bohaterkę w towarzystwie Pála: Znowu ogarnia mnie dziwne uczucie: wegierskie potrawy doprowadzaja mnie niemal do ekstazy. [...] Czujeja [czerwoną paprykę - M.R.-N.] w żotądku. Jem czerwień i czuje, jak ponad moim tonem żyty, skóra i mięśnie zaciskają się niczym sakiewka. Moja pochwa kurczy się, coś we mnie pęka. Jem czerwień, a moje powieki samoistnie zamykaja się, kiedy przetykam ciężkie kawatki, kilkoma ruchami jezyka rozprawiam się z ttuszczami, a w moich ustach pozostaje przyprawiajacy o mrowienie smak owoców, maki i stoniny. Jem czerwień, a tak naprawdę sa to sylaby i stowa, które miażḋe, skręcam, masuje, żuje, maceruje, dusze, jem czerwień i nie musze już mówić, nie musze zważać na stowa, znaki i ich znaczenie, jem czerwień i cata zamieniam się w pomarańczowy, szorstki język, cienki, smukty, kochający jezyk, śpiewajacy i stodki jezyk, żywy jezyk i cate moje podniebienie pokryte jest czerwonym pytem ${ }^{22}$.

22 Une nouvelle fois, j’ai cette étrange sensation: la nourriture hongroise me porte au bord de la jouissance. [...] 
W cytowanym fragmencie na pierwszy plan wysuwa się czerwień, z którą kontakt doprowadza bohaterkę do erotycznego uniesienia. Rozumiana dosłownie czerwień jest czytelną metonimią papryki, będącej głównym składnikiem węgierskich potraw. W planie symbolicznym mowa jest natomiast o szeroko rozumianej węgierskiej tożsamości, do której skonstruowania dąży bohaterka. Przywołane powyżej słowa świadczą o tym, że jest ona bardziej pierwotna niż język, którego znajomość w tym akurat konkretnym momencie życia bohaterki okazała się nie być jej do niczego potrzebna.

Motyw jedzenia jako czynnika tożsamościotwórczego ${ }^{23}$ pojawia się w utworze jeszcze wielokrotnie. Ciekawym przykładem jest m.in. scena opisująca gotowanie galuszek przez Klárę. Jej mama, Zsuzsa, prosi ją, aby przygotowała kolację dla niej i dla jej nowego ukochanego Balázsa. Jako urodzeni na Węgrzech emigranci, którzy większość życia spędzili poza granicami swojej ojczyzny, mają trudności w porozumiewaniu się. Po wielu latach spędzonych w Paryżu w przypadku Zsuzsy i w Londynie w przypadku Balázsa ich jedyny wspólny język, czyli węgierski, jawi się jako obca i dawno zapomniana mowa. Barierę tę mają w zamyśle Zsuzsy przełamać galuszki, o których przygotowanie prosi ona córkę. Klára godzi się na spełnienie prośby matki, mimo iż w jej odczuciu prosi ją ona o dokonanie niemożliwego: odszukanie zapachu, miękkości i smaku dzieciństwa ${ }^{24}$. Tym większa jest radość bohaterki, kiedy okazuje się, że wywiązała się z powierzonego zadania wzorowo, o czym niezbicie świadczą pochwały Balázsa i radość w oczach matki.

Kiedy wydaje się już, że bohaterka uporała się z tożsamościowymi rozterkami i znalazła odpowiedzi na nurtujące ją pytania, okazuje się, że po kądzieli oprócz węgierskich, odziedziczyła również korzenie żydowskie. Żydówką była jej babka, Ilona, która podobnie jak jej dzieci -Zsuzsa i jej brat Endre - po powstaniu węgierskim 1956 r. opuściła Węgry i zamieszkała w Paryżu. Na łożu śmierci kazała przysiąc córce, że nigdy nie zdradzi ona ich wspólnej tajemnicy. Ta dotrzymała słowa, dlatego też Klára przez wiele lat była nieświadoma tego, że ma żydowskie pochodzenie. Ostatecznie historię heroicznej walki Ilony o życie dwójki jej dzieci podczas niemieckiej okupacji poznała Klára dopiero dzięki wujkowi Endremu, który spisał i wydał wspomnienia. Po kilku latach od tej chwili otworzyła się w końcu również matka bohaterki i opowiedziała córce niezwykle bolesną dla niej samej historię dzieciństwa, którą przez wiele lat starała się (jak się później okazało bezskutecznie) wyprzeć z pamięci. Początkowo świadomość wielokulturowej spuścizny rodziny Szelényich jest dla bohaterki powodem niepokoju, wynikającego z potrzeby możliwie jak najbardziej jednoznacznego określenia swojej tożsamości.

Ça me prend en ventre. Je mange rouge et au-dessus du pubis je sens mes veines, ma peau, mes muscles qui se resserrent en bourse. Mon vagin palpite, quelque chose se creuse. Je mange rouge, et je ne peux empêcher mes paupières de se fermer sur ces bouchées pesantes, quand les graisses sétiolent en quelques tours de langue pour laisser ronronner la saveur $d u$ fruit, de la farine et du saindoux. Je mange rouge et ce sont les syllabes, les mots que je broie, je les tords je les masse je les mâche et je les macère, je les étouffe, je les libère, je mange rouge et je n'ai plus à parler, à guetter les signes, les vocables, leur transparence, je mange rouge et je ne suis plus qu'une langue orange, râpeuse, une langue fine, déliée, amoureuse, une langue chantante et doucereuse, une laungue vivante et déjà tout mon palais se couvre de poudre rouge. Tamże, s. 43.

23 Więcej na ten temat zob. „(op.cit.,)” 2012, nr 32 Jedzenie i tożsamość.

24 V. Chocas, Bazar Magyar..., s. 87. 
Ostatecznie dochodzi ona jednak do wniosku, że dziedzictwo, które zostawiły po sobie jej przodkinie, węgierskie Żydówki, to nie tylko niepewność i strach, ale również możliwość wolnego wyboru ${ }^{25}$ i pełna swoboda $\mathrm{w}$ decydowaniu o tym, kim chce się stać.

\section{POSTPAMIĘĆ U PISARZY TRANSJĘZYCZNYCH WĘGIERSKIEGO POCHODZENIA}

Zarówno Ildikó z powieści Nadj Abonji, jak i Klára z utworu Viviane Chocas to bohaterki poszukujące, dla których znalezienie odpowiedzi na pytanie o tożsamość staje się w pewnym momencie głównym życiowym celem. Obie przynależą do więcej niż jednego miejsca, co odróżnia je od większości otaczających je osób i jest powodem ich inności. Łączy je również to, że sytuacji, w której się znalazły, nie „zawdzięczają” samym sobie. Żadna z nich nie podjęła bowiem decyzji o opuszczeniu ojczyzny samodzielnie. Uczynili to za nie ich rodzice, którzy (zapewne w dobrej wierze) zatroszczyli się również o to, aby ich dzieci dorastały nieświadome przeszłości. Obie bohaterki zmuszone były więc same zmierzyć się z rodzinnym dziedzictwem i skonfrontować swoje życie z traumami, które nie dotknęły ich bezpośrednio, a ,jedynie” za pośrednictwem ich rodziców. Docelowo musiały zaś odpowiedzieć na pytanie o to, czy (a jeśli tak, to jak) decyzje podjęte w przeszłości przez ich rodziców wpłynęły na ich życie tu i teraz.

Ildikó zdecydowała się na zarówno symboliczne, jak i fizyczne odcięcie od przeszłości. Porzuciła rodzinny dom, a wraz z nim inicjowane przede wszystkim przez jej rodziców starania o możliwie jak najszybszą i najpełniejszą asymilację w szwajcarskim społeczeństwie. Z kolei dla Kláry tożsamościowe poszukiwania oznaczały konieczność poznania niełatwych losów jej przodków, a ich zwieńczeniem było skonstruowanie nowej, hybrydowej tożsamości, zakorzenionej w aż trzech kręgach kulturowych: francuskim, węgierskim i żydowskim.

Analizowane w niniejszym artykule utwory to niejedyne narracje autorów transjęzycznych pochodzenia węgierskiego, które podejmują problematykę tzw. pamięci odziedziczonej. Podobny mechanizm opisany został m.in. w utworze Sachy Batthyányego - niemieckojęzycznego dziennikarza ze Szwajcarii, potomka starego węgierskiego rodu Batthyányich. A co ja mam z tym wspólnego? Zbrodnia popetniona w marcu 1945. Dzieje mojej rodziny ${ }^{26}$ to pełny tytuł utworu, do którego napisania skłonił autora fakt poznania przez niego historii brutalnej zbrodni, popełnionej ponad 60 lat wcześniej przez członkinię jego rodziny, hrabinę Margit Thyssen-Batthyány. Hrabina urządziła w swoim austriackim pałacu przyjęcie pożegnalne dla miejscowego kierownictwa NSDAP, SS i Gestapo, podczas którego goście „dla zabawy” rozstrzelali przetrzymywanych w pobliżu Żydów. Książka Batthyányiego, podobnie jak utwory Nadj Abonji i Chocas, jest próbą odpowiedzi na pytanie o to, czy decyzje i czyny minionych pokoleń mają wpływ na nasze życie, a jeśli tak, to na ile. Czy prawdą jest, że wszyscy jesteśmy

\section{Tamże, s. 117.}

26 S. Batthyány, A co ja mam z tym wspólnego? Zbrodnia popetniona w marcu 1945. Dzieje mojej rodziny, przeł. E. Bielicka, Warszawa 2017. 
mimowolnie obciążeni przeszłością, i czy możliwe jest w ogóle uwolnienie się od traumy tamtych czasów?

\section{BIBLIOGRAFIA}

Antologia studiów nad trauma, red. T. Łysak, przeł. T. Bilczewski i in., Kraków 2015.

Batthyány S., A co ja mam z tym wspólnego? Zbrodnia popetniona w marcu 1945. Dzieje mojej rodziny, przet. E. Bielicka, Warszawa 2017.

Braidotti R., Podmioty nomadyczne. Ucieleśnienie i różnica seksualna $w$ feminizmie wspótczesnym, przeł. A. Derra, Warszawa 2009.

Chocas, V., Bazar magyar, Paris 2006.

Chocas, V., Je vais beaucoup mieux que mes copains morts, Paris 2012.

Demeter S., Ki a magyariró??, [online] https://mandiner.hu/cikk/20200224_ki_a_magyar_iro.

Diktatúrát Svájcban, Techet Péter beszélgetése Melinda Nadj Abonjival, „Heti Válasz” 2011, 13 I, r. IX, nr 2.

Hirsch M., Żatoba i postpamięć, przeł. K. Bojarska, [w:] Teoria wiedzy o przesztości na tle wspótczesnej humanistyki. Antologia, red. E. Domańska, Poznań 2010.

LaCapra D., Historia w okresie przejściowym. Doświadczenie, tożsamość, teoria krytyczna, przeł. K. Bojarska, Kraków 2009.

Mach A., Świadkowie świadectw. Postpamięć zagtady w polskiej literaturze najnowszej, Warszawa-Toruń 2016.

Migracyjna pamięć, wspólnota, tożsamość, red. R. Sendyka, T. Sapota, R. Nycz, Warszawa 2016. Modi memorandi. Leksykon kultury pamięci, red. M. Saryusz-Wolska, R. Traba; współpr. J. Kalicka, rada nauk. P. Czapliński [i in.], Warszawa 2014.

Nadj Abonji, M., Gotębie wzlatuja, przeł. E. Kalinowska, Wołowiec 2012.

"(op.cit..)" 2012, nr 43 Jedzenie i tożsamość.

„Politeja” 2015, vol. 12, nr 3(35) Oblicza postpamięci.

„Politeja” 2017, vol. 14, nr 2(47) Oblicza postpamięci 2.

„Politeja” 2020, vol. 17, nr 2(65) Oblicza postpamięci 3.

Odpamięci biodziedzicznej do postpamięci, red. T. Szostek, R. Sendyka, R. Nycz, Warszawa 2013. Switching Languages. Translingual Writers Reflect on Their Craft, red. S.G. Kellman, LincolnLondon 2003.

Steinitz T., Translingual Identities. Language and the Self in Stefan Heym and Jakov Lind, Rochester, NY 2013.

Utracka D., Trauma i uwznioślenie. Postpamięćjako kategoria narracyjna (na przyktadzie „Matej Zagtady" Anny Janko), [w:] Tożsamość, kultura, nowoczesność, T. 1, red. B. Morzyńska-Wrzosek, M. Kurkiewicz, I. Szczukowski, Bydgoszcz 2017.

Wojna i postpamięć, red. Z. Majchrowski, W. Owczarski, Gdańsk 2011. 
Magdalena ROGUSKA-NÉMETH - literaturoznawczyni i krytyczka literacka, adiunktka w Katedrze Hungarystyki Uniwersytetu Warszawskiego, autorka monografii poświęconej najnowszej węgierskiej prozie kobiecej (Los niespetniony. O poszukiwaniu tożsamości w wegierskiej prozie kobiecej, 2012) oraz licznych artykułów i rozdziałów w pracach zbiorowych. W obszarze jej zainteresowań naukowych znajdują się m.in. węgierska literatura kobieca, literatura migracyjna, mniejszościowa, transkulturowa, dwu-, wielo- i transjęzyczność. 